J. Japan. Soc. Hort. Sci. 56(2) : 142-150. 1987.

\title{
Effects of High Temperature in the Nighttime and Shading in the Daytime on the Early Drop of Apple Fruit 'Starking Delicious'
}

\author{
Satoru Kondo and Yuzi Takahashi \\ Kazuno Branch, Akita Fruit Tree Experiment Station, Kazuno, Akita 018-52
}

\begin{abstract}
Summary
The daily rate of fruit growth and elongation of the terminal shoots increased under the high night temperature (HNT). Fruit abscission was induced on the trees under NHT from 27 days and 34 days after full bloom (AFB). Under shading from 20 days, 27 days, and 34 days AFB, the daily rate of fruit growth decreased and fruit abscission was induced. The reducing sugar content per fruit was lower in the fruits under shading, in the fruits with interrupted growth and a yellow peduncle.

Ethylene evolution and carbon dioxide production per fruit weight were greater at the early stage of fruit development and increased with the increase of the environmental temperature. AVG application inhibited ethylene evolution and reduced the fruit abscission under a HNT, but hardly under shading.

From these results, it appears that fruit abscission under HNT was caused by the consumption of the nutrients associated with the increase of the vegetative growth and respiration rate and by the amount of ethylene evolved under a high temperature in the nighttime, while fruit abscission under shading was considerably affected by the reduction of the supply of metabolites.
\end{abstract}

\section{Introduction}

A large number of studies on the abscission of immature fruits of apple $(4,30)$, peach $(2,5)$, grape(20), Japanese pers!mmon(32) and cherry (31) have been reported. The phytohormonal substances contained in the fruits $(6,8)$ and the translocation of photosynthates $(22,23)$ have been investigated in detail.

We indicated in a previous report(16) that the early drop of fruit of 'Starking Delicious' apple trees growing under natural environmental conditions was induced by a higher minimum temperature and shorter duration of sunshine. Tukey(27) observed that the early drop of fruit was brought about by heating in the nighttime after petal fall. Moreover, Schneider $(24,25)$ reported that the early drop of fruit was promoted by shading. However, it remains to be determined at

\footnotetext{
1 Received for publication May 14, 1986.
}

which stage of development young fruits are affected by the environmental conditions mentioned above, and whether the early drop of fruits can be accelerated.

This report shows the effects of high temperature in the nighttime and shading in the daytime on apple fruit abscission, fruit growth and elongation of terminal shoots, and the effect of the application of AVG(aminoethoxyvinylglycine) - an inhibitor of ethylene synthesis $(10,21)$ on fruit abscission as well.

\section{Materials and Methods}

1. Effects of high temperature in the nighttime and shading in the daytime on fruit abscission, fruit growth and elongation of terminal shoots

Eight-year-old 'Starking Delicious' apple trees grafted on 'M 26' rootstocks with uniform vigor and crop were selected. Four trees were used for each treatment. In the experiment on the effects of high tempera- 
Table 1. Mean night temperature during the night temperature treatment (1983).

\begin{tabular}{|c|c|c|c|c|c|c|c|c|c|c|c|c|}
\hline \multirow{4}{*}{ treatment } & \multicolumn{12}{|c|}{ Mean night temperature $\left({ }^{\circ} \mathrm{C}\right)(\mathrm{p} . \mathrm{m} .7 .00 \sim$ a. m. 6.00$)$} \\
\hline & \multicolumn{4}{|c|}{ A } & \multicolumn{4}{|c|}{ B } & \multicolumn{4}{|c|}{$\mathrm{C}$} \\
\hline & \multicolumn{2}{|c|}{ May } & \multicolumn{2}{|c|}{ Jun. } & \multicolumn{4}{|c|}{ Jun. } & \multicolumn{4}{|c|}{ Jun. } \\
\hline & 30 & 31 & 1 & 2 & 6 & 7 & 8 & 9 & 13 & 14 & 15 & 16 \\
\hline \multirow[t]{2}{*}{$\mathrm{HNT}^{z}$} & 19.5 & 21.8 & \multirow{2}{*}{\multicolumn{2}{|c|}{$(828.3)^{x}$}} & 20.2 & 18.7 & 21.0 & 20.1 & 20.5 & 18. 4 & 19. 1 & 21.5 \\
\hline & & & & & \multicolumn{4}{|c|}{$(880.0)$} & & & \multicolumn{2}{|c|}{$(874.5)$} \\
\hline \multirow[t]{2}{*}{$\mathrm{NEC}^{\mathrm{y}}$} & 16.1 & 17. 6 & 11.1 & 9.8 & 16.2 & 13. 1 & 15.8 & 14.7 & 14.1 & 12.9 & 14.4 & 16. 4 \\
\hline & & & \multicolumn{2}{|c|}{$(600.6)$} & \multicolumn{4}{|c|}{$(657.8)$} & & & \multicolumn{2}{|c|}{$(635.8)$} \\
\hline
\end{tabular}

z HNT : High night temperature obtained by heating the pipe-house.

y NEC : Natural environmental conditions (mean night temperature outdoors).

$\mathrm{x}$ The total night temperature between p.m.7.00 and a.m.6.00 for 4 days.

ture in the nighttime, apple trees were enclosed in a pipe frame greenhouse covered with a $0.1 \mathrm{~mm}$ clear polyvinyl chloride film, in which a warm-air heating apparatus with a thermostat was operated during the night. The temperature treatments shown in Table 1 were continued for 4 days as follows, respectively; A : from May 30 (20 days after full bloom (AFB)), B : from June 6 (27 days $\mathrm{AFB}$ ) and $\mathrm{C}$ : from June 13 (34 days $\mathrm{AFB}$ ) in 1983. The polyvinyl film covering the pipe-house was opened during the day to avoid extremely high temperature and excessive shading of the trees. For the test of shading in the daytime, apple trees were enclosed in a similar pipe-house covered with a cheesecloth whose shading ratio was $51 \%$. The shading treatments were applied continuously for 4 days as follows; A, B and $\mathrm{C}$ as mentioned above and D: from June 20 (41 days AFB).

Central flowers of a cluster which were hand-pollinated with the pollen of 'Ohlin' on May 10 when they were in full bloom were used in the experiment and all the lateral fruits of a cluster were thinned on May 26. The fifty fruits and the twenty terminal shoots which had grown uniformly were marked just before the treatments. The terminal shoots were selected in the same manner as in the previous report(16). The number of fruits remaining on the trees was recorded regularly from the beginning of each treatment to the day when fruit abscission ceased. The diameter of the fruit equatorial part and the elongation of the terminal shoots were measured every day during the treat- ments for 4 days. In addition, the reducing sugar contents of the following fruits were analyzed every week from June 3 (24 days AFB) ; A : fruits growing uniformly under natural environmental conditions, $B$ : fruits growing uniformly under high night temperature conditions for 4 days, $\mathrm{C}$ : fruits growing uniformly under shading for 4 days, D : fruits with interrupted growth, E: fruits with yellow peduncle. The fruits were ground into a fine powder after freeze-drying and kept at $-20^{\circ} \mathrm{C}$ till analysis. The Determination of the reducing sugar content was performed by applying the Somogyi-Nelson's method.

2. Ethylene evolution and carbon dioxide production from young fruits and effect of AVG on fruit abscission

The fruits for ethylene and carbon dioxide analysis at $13^{\circ} \mathrm{C}, 20^{\circ} \mathrm{C}$ and $25^{\circ} \mathrm{C}$ were collected every week from May 31 (21 days AFB) in 1983. The effect of AVG on fruit abscission was investigated under both the high night temperature and shading treatments in 1984. Nine-year-old 'Starking Delicious' apple trees grafted on 'M 26' rootstocks were used. The high night temperature treatment was applied continuously for 7 days from June 14 (19 days AFB) and shading was applied for 5 days from June 13 (18 days AFB), respectively. Fifty fruits for each treatment were sprayed with a $200 \mathrm{ppm}$ AVG solution containing $0.1 \%$ Atlox BI on June 13. The number of fruits remaining on the trees was recorded at regular intervals until July 7 . On the other hand, the fruits grown under natural environmental conditions were spray- 
ed with a $200 \mathrm{ppm}$ AVG solution mixed with $0.1 \%$ Atlox BI on June 13 and ethylene and carbon dioxide production from the fruits was regularly analyzed.

Three fruits, whose transverse diameters were approximately the same, were enclosed in $100-300 \mathrm{ml}$ glass vials after the determination of the fruit weight. The fruits in the sealed vials were kept in the dark in a controlled room at $20^{\circ} \mathrm{C}$ for 15 hours. Two ml gas sample for ethylene and carbon dioxide analysis was collected from the head-space in the vials by a pressure-lock gas syringe. Ethylene and carbon dioxide concentrations were estimated by gas-chromatography $\left(\mathrm{Hi}^{-}\right.$ tachi Model 163) under the following conditions ; column, porapak Q(80-100 mesh), steel column, $3 \mathrm{~mm} \phi \times 2 \mathrm{~m}$; column temperature, $60^{\circ} \mathrm{C}$; carrier gas, He $30 \mathrm{ml} / \mathrm{min}$; injection temperature, $70^{\circ} \mathrm{C}$; detector, TCD (carbon dioxide), FID (ethylene).

\section{Results}

1. Effects of high temperature in the nighttime and shading in the daytime on fruit abscission, fruit growth and elongation of terminal shoots

Fig. 1 shows the effects of high night temperature (HNT) and shading on fruit abscission. In the treatments applied 20 days $\mathrm{AFB}$, the mean night temperature under HNT was $3.4-6.9^{\circ} \mathrm{C}$ higher than that under natural environmental conditions (NEC).
The final rate of fruit abscission amounted to $18.0 \%$ under HNT and $26.0 \%$ under NEC. The fruits on the trees under shading showed a high rate of abscission 3-5 days after the treatment and the final rate amounted to 90.0 $\%$. In the treatments applied 27 days AFB, the mean night temperature under $\mathrm{HNT}$ was 4. $0-5.6^{\circ} \mathrm{C}$ higher than that under NEC. The fruits under HNT underwent abscission 8 days after the treatment and the final rate of fruit abscission amounted to $34.0 \%$. The fruits under NEC did not show any evidence of abscission. The fruits on the trees under shading experienced abscission 3 days after the beginning of the shading and the final rate of fruit abscission amounted to $36.0 \%$. In the treatments applied 34 days AFB, the mean night temperature under $\mathrm{HNT}$ was 4. 7-6. $4^{\circ} \mathrm{C}$ higher than that under NEC. The fruits under both the HNT and shading underwent abscission 5 days after the treatment and the final rate of fruit abscission was 12.0 $\%$ and $22.0 \%$, respectively. The fruits under NEC did not display abscission. In the treatments applied 41 days AFB, the fruits failed to experience abscission under both the shading and NEC. Thus, although the HNT applied 20 days AFB did not induce fruit abscission, the HNT applied 27 days AFB and the shading applied 20 days AFB affected most severely fruit abscission, and thereafter, these effects reduced when the treatment was delayed, respectively.
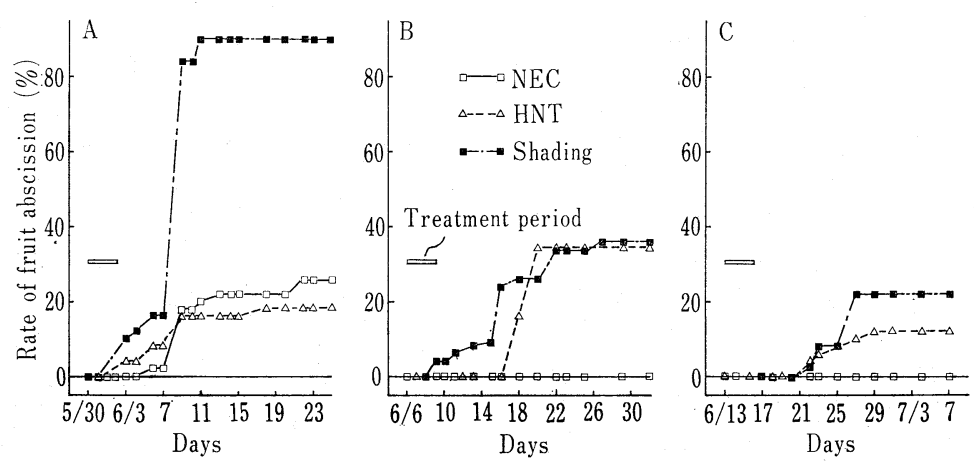

Fig. 1. Effects of high night temperature and shading treatments on fruit abscission (1983). The treatments were applied for 4 days from (A) : 20 days, (B) : 27 days and (C) : 34 days after full bloom, respectively. NEC : Natural environmental conditions. HNT : High night temperature.

Rate of fruit abscission is expressed as $\%$ of fruits treated. 


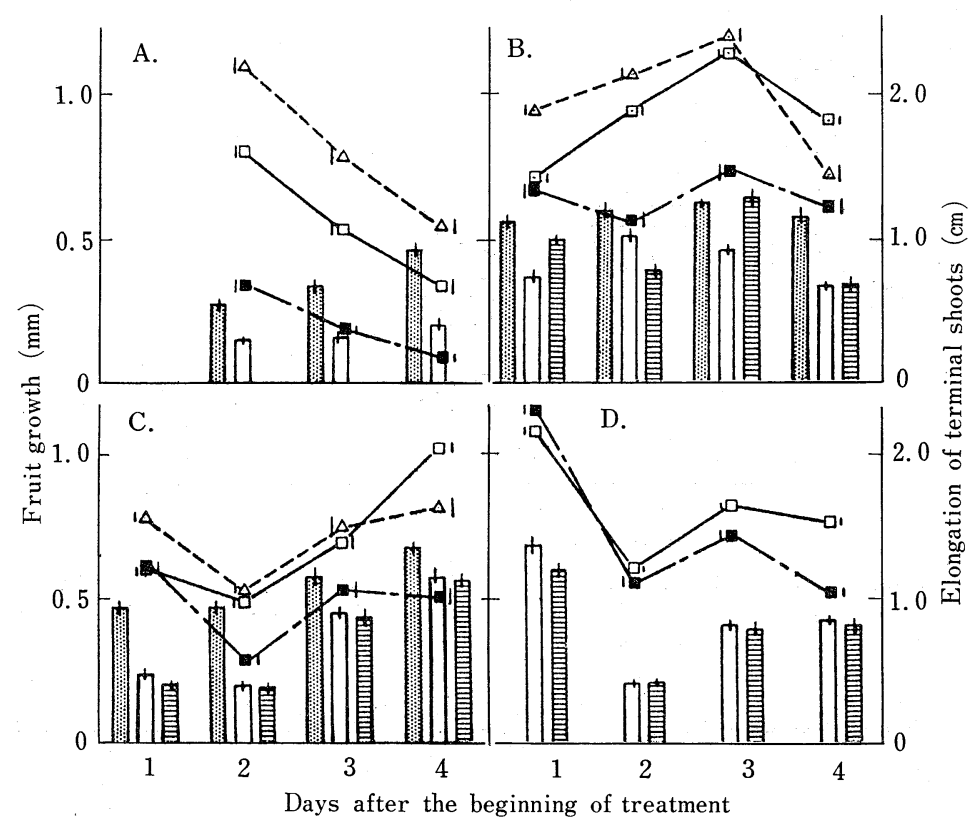

Fruit growth : $\square-\square$ Natural environmental conditions,

$\Delta---\Delta$ High night temperature,

Shading. Elongation of

terminal shoots :

Natural environmental conditions,

High night temperature, 血血血血 Shading.

Fig. 2. Effects of high night temperature and shading treatments on the daily rate of fruit growth and elongation of terminal shoots (1983).

The treatments were applied for 4 days from (A) : 20 days, (B) : 27 days, (C) : 34 days and

(D) : 41 days after full bloom, respectively. Vertical bars indicate S. E. .

Fig. 2 shows the effects of these treatments on fruit growth and elongation of terminal shoots. The daily rate of fruit growth and elongation of terminal shoots increased under HNT. However, in the treatment applied 27 days and 34 days AFB, several fruits under HNT ceased growing, and the fruit growth rate on the 4 th day after the beginning of HNT decreased in comparison with that under NEC. These fruits under HNT exhibited abscission within 10 days. On the other hand, the daily rate of fruit growth under shading decreased regardless of the time of treatment. But the shading had little effect on the elongation of the terminal shoots. The reducing sugar content per gram dry weight of fruit hardly differed between the fruits, hut the content per fruit was lower in the fruits under shading, in the fruits with arrested growth and a yellow peduncle (Table 2).
Table 2. Reducing sugar content of fruits collected at various stages (1983).

\begin{tabular}{ccccc}
\hline Fruit & $\begin{array}{c}\text { Jun. } 3 \\
(24 \text { days })^{\mathbf{z}}\end{array}$ & $\begin{array}{c}\text { Jun. 10 } \\
(31 \text { days })\end{array}$ & $\begin{array}{c}\text { Jun. } 17 \\
(38 \text { days })\end{array}$ & $\begin{array}{c}\text { Jun. 24 } \\
(45 \text { days })\end{array}$ \\
\hline A & $26.0^{\mathrm{y}}$ & 33.2 & 40.3 & 49.1 \\
& $(9.4)^{\mathrm{x}}$ & $(25.7)$ & $(46.8)$ & $(113.3)$ \\
B & 26.3 & 35.1 & 42.0 & \\
& $(10.1)$ & $(28.4)$ & $(57.6)$ & \\
C & 28.1 & 35.1 & 42.1 & 48.4 \\
& $(5.0)$ & $(20.4)$ & $(47.3)$ & $(112.4)$ \\
D & 27.2 & 37.6 & 40.5 & 48.9 \\
& $(3.7)$ & $(10.7)$ & $(20.1)$ & $(46.3)$ \\
E & 26.0 & 34.0 & 41.5 & 48.2 \\
& $(2.3)$ & $(8.2)$ & $(14.0)$ & $(41.7)$ \\
\hline
\end{tabular}

A : Fruit growing uniformly under natural environmental conditions.

B : Fruit growing uniformly under a high night temperature for 4 days.

C : Fruit growing uniformly under shading for 4 days.

D : Fruit with interrupted growth.

E : Fruit with yellow peduncle.

z Days after full bloom

y $\mathrm{mg} /$ gram d.w. $\quad x \mathrm{mg} /$ fruit 

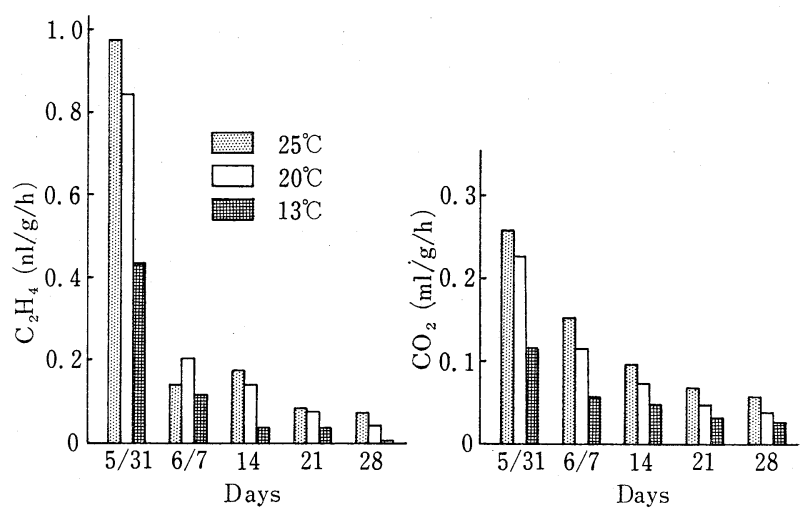

Fig. 3. $\mathrm{C}_{2} \mathrm{H}_{4}$ and $\mathrm{CO}_{2}$ production from fruit under various temperature conditions (1983).

Young fruits were collected every week from 21 days after full bloom (May 31) and kept at $25^{\circ} \mathrm{C}$, $20^{\circ} \mathrm{C}$ and $13^{\circ} \mathrm{C}$ for 15 hours, respectively.

Table 3. Effect of AVG application on the $\mathrm{C}_{2} \mathrm{H}_{4}$ evolution and $\mathrm{CO}_{2}$ production from fruit (1984).

\begin{tabular}{|c|c|c|c|c|c|c|c|c|c|c|c|c|}
\hline \multirow{3}{*}{ treatment } & \multicolumn{6}{|c|}{$\mathrm{C}_{2} \mathrm{H}_{4} \mathrm{nl}\left(\times 10^{3}\right) / \mathrm{g} / \mathrm{h}$} & \multicolumn{6}{|c|}{$\mathrm{CO}_{2} \mathrm{ml}\left(\times 10^{3}\right) / \mathrm{g} / \mathrm{h}$} \\
\hline & \multicolumn{6}{|c|}{ Jun. } & \multicolumn{6}{|c|}{ Jun. } \\
\hline & 15 & 17 & 20 & 23 & 26 & 29 & 15 & 17 & 20 & 23 & 26 & 29 \\
\hline AVG & 144 & 5 & 5 & 2 & 19 & 18 & 119 & 89 & 71 & 78 & 86 & 51 \\
\hline control & 167 & 29 & 43 & 24 & 22 & 15 & 110 & 86 & 75 & 71 & 79 & 44 \\
\hline
\end{tabular}

AVG (200 ppm solution) was applied on Jun. 13 (18 days after full bloom).

\section{Ethylene evolution and carbon dioxide} production from young apple fruits and effect of $A V G$ on fruit abscission

Fig. 3 shows the ethylene and carbon dioxide production from young fruit under various temperature conditions. Ethylene evolution and carbon dioxide production per fruit weight were greater at the young stage of fruit and increased with the increase of the environmental temperature. The ethylene evolution from fruits sprayed with AVG decreased markedly and was inhibited from $1 / 6$ to $1 / 12$ for 3-9 days after AVG application (Table 3). However, the effect of AVG application on the carbon dioxide production from fruit was uncertain.

Fig. 4 shows the effect of AVG on fruit abscission. Under HNT where the mean night temperature for 7 days was $24.1^{\circ} \mathrm{C}$, the abscission rate of the fruits sprayed with AVG was $14.0 \%$ whereas that of the fruits which had not been sprayed with AVG was 46. $0 \%$. Thus, AVG application markedly reduced fruit abscission under HNT. On the other hand, the abscission rate of the fruits sprayed with AVG was $78.0 \%$ whereas that of the fruits without AVG spraying was 85.0 $\%$ under shading applied for 6 days, and the effect of AVG application was a little under shading.

\section{Discussion}

In this report, it was confirmed that fruit abscission was induced by the short HNT and shading treatments for about 40 days AFB. It was previously reported that the fruit growth rate increased by HNT applied from the early stage of fruit development $(26,28)$. The results of this study are in agreement with the reports mentioned above and the elongation of the terminal shoots was also increased by HNT. Thus, the fruit size and vegetative growth were stimulated at a high minimum temperature but fruit abscission was also induced. Therefore, the effect of the temperature on ethylene and carbon dioxide production from young fruits was investigated, and it was shown that the production increased with the increase of the temperature. A large number of reports have indi- 


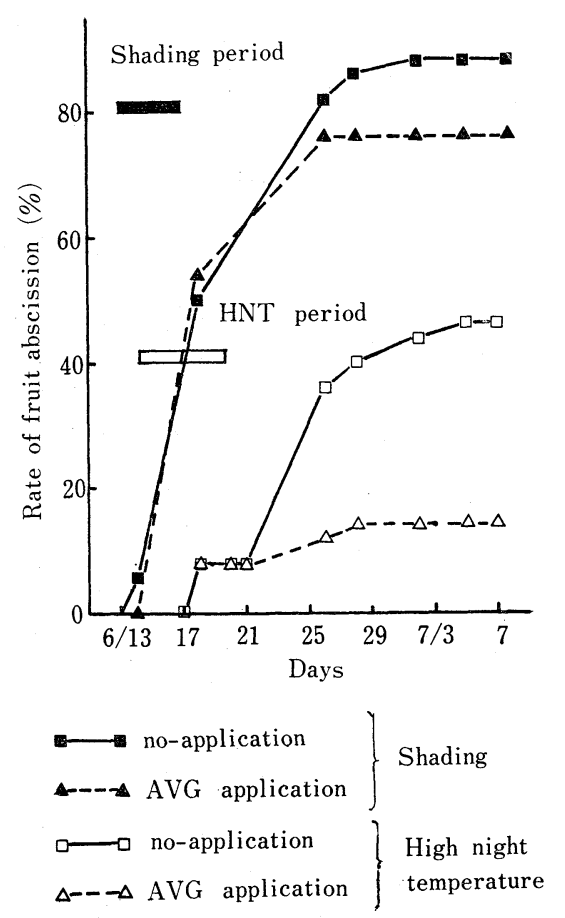

Fig. 4. Effects of AVG application under high night temperature and shading treatments on fruit abscission (1984).

AVG (200 ppm solution) was applied on June 13 (18 days after full bloom). The high night temperature treatment (HNT) was applied on Jun. 14-20. The shading treatment was applied on Jun. 13-17.

cated that fruit abscission is induced by ethylene $(3,4,5,18,20,29,31)$. Chiba and Kubota(3) reported that physiological fruit abscission was related to ethylene evolution in apple fruits and was accelerated in cultivars with a high ethylene evolution. In this study, AVG application markedly reduced ethylene evolution from fruit, although the effect on carbon dioxide production was uncertain, and fruit abscission was reduced under HNT. These results suggest that ethylene evolution is closely related to fruit abscission.

Schneider(24) reported that the translocation of sucrose from foliage to fruit in peach was reduced by ethephon application. Weinbaum et al. (29) also showed that the transport of IAA and sucrose through the peach pedicel was reduced by ethephon application and these effects were more pronounced in smaller fruits. Moreover, Iwahori and Oohata
(14) indicated that the cellulase activity in the leaf abscission zones of 'Satsuma' mandarin was enhanced by ethephon application. Several reports on the effects of AVG on fruit abscission indicate that the fruit set was promoted by the spraying of a $200 \mathrm{ppm}$ solution on trees in full bloom $(7,11)$, by the application of a $1000 \mathrm{ppm} \mathrm{AVG}$ two weeks $\mathrm{AFB}(30)$, $250 \mathrm{ppm}$ AVG on trees in full bloom(12) and $500 \mathrm{ppm}$ AVG in the preharvest period of the preceding year(13). Although in these reports the time of application and the concentrations varied, the early drop of fruit was inhibited by all the applications of AVG. Williams(30) and Greene(11) showed that the promotion of fruit set by AVG application was associated with the reduction of endogenous ethylene production. According to these reports and the results of this study, it appears that fruit abscission of trees under HNT was caused by the following mechanism. Since the consumption of nutrients in the tree increased with the increase of the vegetative growth and respiration rate, competition among fruits took place. In addition, a large amount of ethylene was produced under a HNT and ethylene evolution affected the translocation of nutrients $(24,29)$, plant growth substances(29) and the formation of an abscission layer(14). As a result the fruits whose supply of nutrients was lower underwent abscission.

Nito(20) reported in grape fruit that ethylene evolution was induced with the increase of the auxin content, and that an abscission layer was formed leading to fruit abscission. However, Fukui et al. (9) indicated that in apple fruit ethylene evolution and the formation of an abscission layer were not observed immediately after the interruption of fruit growth, suggesting that these factors were not the primary factors causing fruit abscission. Moreover, Greene(12) indicated that AVG application in the preharvest period which promoted the fruit set in the following year did not affect the ethylene levels in the flowers, fruits and leaves produced in the following year. Thus, the mechanism controlling fruit abscission by ethylene has not yet been fully elucidated. In the current ex- 
periment, AVG application under shading hardly inhibited fruit abscission. Therefore, studies should be carried out on the other factors responsible for the reduction of fruit abscission as well as on the inhibition of ethylene evolution.

The results of the current experiment indicate that the reducing sugar content per gram dry weight of fruit showed few differences among the fruits but that the content per fruit was lower in the fruits under shading compared with the fruits under NEC. Furthermore, the daily rate of fruit growth was decreased and fruit abscission was promoted in the trees under shading. Kuroda et al. (17) reported that the set of peach fruits supplied with sucrose was promoted. Schneider(23) also showed that the reduced translocation of sucrose was an important factor in fruit abscission. Besides, it has been shown that although the compensation point of apple leaves is less than $2 \%$ of full sunlight(107600 lux) (15), the leaves require the light intensity of about 15000 lux for sufficient assimilation(1) and net photosynthesis of leaves on 'Delicious' trees increases with the light intensity(19). These results tend to suggest that the supply of metabolites to fruit was reduced under shading, and that fruit abscission was induced.

\section{Literature Cited}

1. AOKI, J. 1975. Studies of apple. p. 61-63. Tsugaru Shoboh, Hirosaki. (In Japanese)

2. Byers, R. E. and C. G. LyONS, Jr. 1984. Peach fruit abscission by shading and photosynthetic inhibition. HortScience $19: 649-651$.

3. ChiBA, K. and T. KubotA. 1979. Fruit drop, ethylene evolution and the effects of 1-naphthyl N-methylcarbamate on them in apple fruitlets. Bull. Fruit Tree Res. Stn. C 6 : 55-64. (In Japanese with English summary)

4. Chiba, K., T. Kubota and T. Suyama. 1980. Effects of 2-chloroethylphosphonic acid(ethrel) on abscission, growth and ethylene evolution of apple fruitlets. Bull. Fruit Tree Res. Stn. C $7: 63-74$. (In Japanese with English summary)

5. DANIELl, J. W. and R. E. WILKINSON. 1972. Effect of ethephon-induced ethylene on abscission of leaves and fruits of peaches. J. Amer. Soc. Hort. Sci. $97: 682-685$.
6. DenNis Jr., F.G. 1976. Gibberellin-like substances in apple seeds and fruit flesh. J. Amer. Soc. Hort. Sci. 101:629-633.

7. DENNIS Jr., F. G., D. D. ARCHBOLD and C.O. VECINO. 1983. Effects of inhibitors of ethylene synthesis or action, $\mathrm{GA}_{4+7}$, and $\mathrm{BA}$ on fruit set of apple, sour cherry, and plum. J. Amer. Soc. Hort. Sci. $108: 570-573$.

8. FUKUi, H., S. ImakaWa and T. TAMURA. 1984. Histochemical observation and quantitative analysis of indole delivatives in apple seeds in relation to early drop of fruit. J. Japan. Soc. Hort. Sci. 53:135-140. (In Japanese with English summary)

9. FUKUi, H., S. ImaKaWA and T. TAMURA. 1984. Relation between early drop of apple fruit, ethylene evolution and formation of abscission layer. J. Japan. Soc. Hort. Sci. 53 : 303-307. (In Japanese with English summary)

10. Gavinlertvatana, P., P. E. Read and H. F. WILKINS. 1980. Control of ethylene synthesis and action by silver nitrate and rhizobitoxine in petunia leaf sections cultured in vitro. J. Amer. Soc. Hort. Sci. $105: 304-307$.

11. GREENE, D.W. 1980. Effect of silver nitrate, aminoethoxyvinylglycine, and gibberellins $A_{4+7}$ plus 6-benzylamino purine on fruit set and development of 'Delicious' apples. J. Amer. Soc. Hort. Sci. $105: 717-720$.

12. GREENE, D. W. 1983. Some effects of AVG on fruit set, fruit characteristics, and vegetative growth of apple trees. J. Amer. Soc. Hort. Sci. $108: 410-415$.

13. GREENE, D. W. 1983. Effect of chemical thinners on fruit set and fruit characteristics of AVG-treated apples. J. Amer. Soc. Hort. Sci. $108: 415-419$.

14. IWAHORI, S. and J. T. OOHATA. 1976. Chemical thinning of 'Satsuma' mandarin (Citrus unshiu MARC.) fruit by 1-naphthaleneacetic acid: role of ethylene and cellulase. Scientia Hort. $4: 167-174$.

15. JACKSON, J.E. 1980. Light interception and utilization by orchard systems. Hort. Rev. $2: 208-267$.

16. Kondo, S., M. Asari and M. Kumagai. 1987. Effects of weather conditions, tree vigor, and pruning on the early fruit drop of apple. J. Japan. Soc. Hort. Sci. (In Press) (In Japanese with English summary)

17. KURODA, K., G. OKAMoto and T. FUKUda. 1970. Studies on the physiological dropping of peach. Abstr. Japan. Soc. Hort. Sci. Autumn Meet. 1970. p. 20-21. (In Japanese) 
18. LiPE, J. A. and P.W. MORGAN. 1972. Ethylene : role in fruit abscission and dehiscence processes. Plant Physiol. 50 : 759-764.

19. MARINI, R. P. and J. A. BARDEN. 1982. Net photosynthesis, dark respiration, transpiration, and stomatal resistance of young and mature apple trees as influenced by summer or dormant pruning. J. Amer Soc. Hort. Sci. $107: 170-174$.

20. Nito, N. 1985. Role of endogenous auxin and ethylene on the excessive flower and berry abscission (coulure) in 'Kyoho' grape. Bull. Fac. Agr., Saga Univ. 58:1-44. (In Japanese with English summary)

21. OWEns, L. D., M. LIEBERMAN and A. Kunishi. 1971. Inhibition of ethylene production by rhizobitoxine. Plant Physiol. $48: 1-4$.

22. SCHNEIDER, G. W. 1973. Translocation of ${ }^{14} \mathrm{C}-$ indoleacetic acid and ${ }^{14} \mathrm{C}$-sucrose in excised apple pedicels. J. Amer. Soc. Hort. Sci. $98: 278-281$.

23. SCHNEIdER, G. W. 1975. ${ }^{14} \mathrm{C}$-sucrose translocation in apple. J. Amer. Soc. Hort. Sci. $100: 22-24$.

24. SCHNEIDER, G. W. 1977. Studies on the mechanism of fruit abscission in apple and peach. J. Amer. Soc. Hort. Sci. $102: 179-181$.

25. SCHNEIDER, G. W. 1978. Abscission mechanism studies with apple fruitlets. J. Amer. Soc. Hort. Sci. 103 : 455-458.

26. TAMURA, T., H. FUKUI, S. ImAKAWA and Y. MiNo. 1981. Effect of temperature at early stage of fruit development on the development of fruit and seed in apple. J. Japan. Soc. Hort. Sci. $50: 287-296$. (In Japanese with English summary)

27. TUKEY, L. D. 1956. Some effects of night temperatures on the growth of 'McIntosh' apples, I. Proc. Amer. Soc. Hort. Sci. $68: 32-43$.

28. TukEY, L. D. 1959. Some effects of night temperature on the growth of 'McIntosh' apples, II. Proc. Amer. Soc. Hort. Sci. 75 : 39-46.

29. Weinbaum, S. A., C. Giulivo and A. Ramina. 1977. Chemical thinning : ethylene and pretreatment fruit size influence enlargement, auxin transport, and apparent sink strength of french prune and 'Andross' peach. J. Amer. Soc. Hort. Sci. $102: 781-785$.

30. Williams, M. W. 1980. Relation of fruit firmness and increase in vegetative growth and fruit set of apples with aminoethoxyvinylglycine. HortScience $15: 76-77$.

31. Wittenbach, V. A. and M. J. Bukovac. 1975. Cherry fruit abscission: a role for ethylene in mechanically induced abscission of immature fruits. J. Amer. Soc. Hort. Sci. 100 : 302-306.

32. YAmAMURA, H. and R. NAITO. 1975. Mechanism of the thinning action of NAA in kaki fruits. 1. Relation between NAA-induced fruit abscission and endogenous growth substances in fruit tissues. J. Japan. Soc. Hort. Sci. $43: 406-414$. (In Japanese with English summary)

\title{
夜間高温および遮光がリンゴ ‘スターキング・デリシャス’ \\ の早期落果に及汸す影響
}

\section{近藤悟・高橋 佑治}

秋田県果樹試験場鹿角分場０18-52 鹿角市花輪

\begin{abstract}
摘 要
‘スターキング・デリシャス’を用い，前報にもとづ き早期落果の程度を助長する気象条件について調査し た。満開後20日，27日拉よび34日から開始した夜間高温 処理を，また，満開後20日，27日，34日拈よび41日の各 々から開始した遮光処理を，それぞれ 4 日間づつ同時間 処理し, 果実の落果率や肥大度, 新梢伸長などに及法す 影響を調查した。また，AVG 散布の果実落果に及ぼす 影響についても検討した.

夜間高温処理は，果実肥大特よび新梢伸長を増加させ

た、しかしながら，満開27日後，34日後からの処理は果 実落果を增加させ, 特に満開27日後からの処理の影響が 大きかった. 一方, 遮光処理は, 満開20日後, 27 日後掠 よび34日後からの処理が落果を誘発し，処理開始ととも に果実肥大を抑制した。果実あたりの糖含量は, 遮光処 理下の果実, 肥大の停止した果実括よび果梗の黄変した 果実で低かった。

果重あたりのエチレン発生量および呼吸量は, 生育の ステージが早いほど，また温度が高いほど多くなった。
\end{abstract}


AVG 散布は果実からのエチレン発生を抑制し，夜間高 温処理下では落果率を減少させた，乙かしながら，遮光 処理下ではその効果は低かった。

このようなことから, 夜間高温処理下に抢ける落果は 栄養生長特よび呼吸の增加により養分が消費されたこと
に加え, 高温によるエチレン発生が落果に影響を及ぼし たものと推察される. また遮光処理下では, 果実への光 合成産物の供給の減少が最も大きく影響したと考兄られ た。 